Integritas 2.1 (Fall 2013), pp. 15-20.

doi: $10.6017 /$ integritas.v2i1p15

\title{
Response to Thomas G. Plante
}

\author{
Kevin L. Hughes
}

"Be Not Conformed to this World, but Be Transformed by the
Renewal of Your Mind, that you may prove what is the will of
God, what is good and acceptable and perfect."

(Rom. 12:2)

First let me thank Tom for his paper, and for the genuine spirit of hopefulness which oozes from the pores of the paper. I don't know Tom, except for our brief encounters at our last gathering and brief conversation last night, but I can see in this paper someone who delights to dwell at the heart of the Catholic and Jesuit mission of his home institution. For that, I'm grateful.

Tom's paper begins where so many of us have to begin, with the overall sense of crisis in university education as a whole, and a more acute crisis still in liberal arts education, and so that is where I will begin my comments too.

On the first, Tom points to Peter Thiel's "anti-scholarship" that pays for students to drop out of college as an example of one emerging school of thought which doubts the value prospect of a college degree as such. He then gives a succinct and poignant litany of the "woes of the bachelor": "The continuing rising costs of higher education, the inability of many college graduates to find satisfying, relevant, and gainful employment

Kevin L. Hughes is an Associate Professor of Theology and Religious Studies and Chair of both the Humanities Department and Classical Studies Program at Villanova University. His research specialties are in Ancient and Medieval Christian theology, spirituality, and history. Among his books are Augustine and Liberal Education; Constructing Antichrist; and Church History: Faith Handed On. His articles have appeared in journals such as Modern Theology; The Heythrop Journal; Theological Studies; and Franciscan Studies. 
within their areas of study after graduation, the increase in and acceptance of long-term unpaid internships...the higher expectations for luxury and glamorous living...." To these we might add the evolving face of education, from MOOCs to badges and certifications, all of which have begun to chip away at the inevitability of the four-year college experience for middle-class success, an inevitability that we have assumed, I think, since the great influx resulting from the GI bill in the wake of World War II (51\%), Korea (43\%), and above all Vietnam (72\%). ${ }^{\mathrm{I}}$ We seem to live at the end of that era of inevitability, and we simply don't know what that will mean for our colleges and universities. It's likely to lead to a great culling, where smaller regional colleges and universities will either close or change, becoming vendors of various online certifications. Our larger institutions will be here, but will serve a smaller population, and, in that case, we will be left to consider who those students are and what it is that they need from us.

From these general considerations we turn to the more acute question of the crisis in the liberal arts. Tom's paper anticipates the anxious parent's or prospective student's questions, Why should students consider majoring in liberal arts academic disciplines in 2013 and beyond? Is it foolish for today's college students to major in the humanities, performing arts, social sciences, and even natural sciences when the business, computer science, and engineering fields are so much more marketable, profitable, and popular? Could it be that a liberal arts education is only for those who are independently wealthy and those who won't need to worry about earning a living after graduation? And students, it seems, are answering these questions, as it were, with their feet. Harvard University made headlines this summer with the publication in June of The Teaching of the Arts and Humanities at Harvard College: Mapping the Future, their internal study of trends at Harvard over the last Io years, where concentrators in arts and humanities have dropped from $2 \mathrm{I}$ to $\mathrm{I} 7$ percent. The report notes:

more than half of students who as pre-Freshmen indicate an intention to concentrate in a Humanities concentration end up in a different division: $50 \%$ graduate in a social science, $27 \%$ in either Government (II\%), Psychology (8\%), or Economics (8\%). ${ }^{2}$

Indeed, this trend spreads much wider than Harvard, with some institutions reporting a $20 \%$ decline in applications to colleges of liberal arts or arts and letters over a two- to four-year period. If we're committed to the transcendent value of the liberal arts, it is not clear that we are getting the message across, whether we are at our national

1 M. Greenberg, "How the GI Bill Changed Education," Chronicle of Higher Education, June 18, 2004, B9-11.

The Teaching of the Arts and Humanities at Harvard College: Mapping the Future, online at http:// harvardmagazine.com/sites/default/files/Mapping the Future of the Humanities.pdf. As an aside, it's worth noting that the report takes the time to disarm the objection that this problem is specific to Harvard, and indeed, it is not. Universities across the country are experiencing a shift; a steady decline in applicants to colleges of liberal arts and sciences or arts and letters over the last half-decade. The fear of vulnerability keeps many institutions from sharing their data, and such a conspiracy of silence diminishes our capacity to respond collectively with our best resources. 
standard-bearer or at the variety of institutions we here assembled represent. This is quite a bit of bad news to sustain, and, at this point, at a meeting like this, I feel a bit like a storm crow- “Ill news is an ill guest." But here is where I can take heart from Tom's paper, because I share with him the conviction that the solution to the crisis in the liberal arts (and perhaps part of a way of addressing the larger question about the university itself) is really to double down, to reinvest in rather than divest from the liberal arts. But how do we do this? How do we make a case for the liberal arts?

One strategy of response is to argue for the competitive edge of the flexible skill set accumulated in the course of a liberal arts education. Tom's paper cites a study by Hart Research Associates that indicates employers' preference for "demonstrated capacity to think critically, communicate clearly, and solve complex problems" is more important than a student's major, and that "ethical judgment" and "ease of working with diverse cultural backgrounds [sic]" is important. For Tom, this is good news, that the market actually prefers the skills cultivated by a liberal arts program. It is here that I would raise my first question. Is it the case that these skills, critical thinking, ethical judgment, and/ or ease with people with diverse cultural backgrounds are goods particular in any way to a liberal arts education? At my own institution, I often find that our engineers and business students, who have been trained to work collaboratively on group projects built around problem solving and have honed skills in public presentation, are as well or better equipped in these areas than my liberal arts students. I agree with Tom when he says that "critical thinking and problem-solving skills based on thoughtful and critical analysis as well as the ability to appreciate, work with, and even celebrate diversity never goes out of style." I am just not sure that these skills are distinctively and uniquely provided by a liberal arts education. It may not even be what we do best.

Indeed, I want to go so far as to suggest that, as soon as proponents of the liberal arts aim to "compete" in the market of skill acquisition, they have already lost, since a liberal arts education is not, properly and distinctively, ordered to the acquisition of skills but to the cultivation of the habitus, the disposition, of a "philosopher" in the most flatfooted sense, the lover of wisdom. (The fact that advanced liberal arts degrees are usually Ph.D.s no matter what discipline is not accidental.) One would speak better of habits or capacities such as "wonder," "patience," "contemplation," "empathy," "conviction," and "compassion" as closer to the proper end of liberal arts education. Those are the sorts of things we do really well when we do them well, and they are harder to find in the engineering, business, or nursing classrooms. I had a class this week, in my Humanities course called Dante and Theology, in which we were sharing in Dante's heart-wrenching lament at Virgil's departure in the Purgatorio, and we were all enrapt, on the knife's edge of beauty and loss, and wondering what hope we might have for poor Virgil after all that. We drew upon all the verbal and syntactical allusions to Virgil's Aeneid and Georgics; we looked back and forth from the Italian to the English translation, and, for a few minutes, we pushed the books to the center of the table and speculated together. When class ended, several students lagged behind, as we were all reluctant to end the conversation, 
and one said to me, "I don't know when I've ever felt this alive...." These are the kinds of things we can do well, and we become more deeply human when we do them. Training into such a habitus may bring with it collateral skills like "critical thinking" or "communication," but these are collateral skills, partially rather than substantially related to the heart of the matter, and they may be found in equal or greater measure in those other forms of education.

I suspect what I have said sounds starry-eyed, impractical, and maybe even risible. Indeed, it is difficult to imagine the employers that the Hart firm consulted saying that they were looking for applicants with a love of wisdom and a capacity for wonder and contemplation. My student might tell a story about that class on Dante and Virgil in an interview, and it might delight the potential employer, but it is not likely to be the difference when dollars and cents are on the line. I do have one former student, a Humanities and Mathematics double-major, who talked about Plato's Republic in his successful interview with Lockheed Martin when he was asked about models of collaboration. But the essential part of this story is that, without his skills in mathematics and statistics, he would not have made it into that interview room to start with. He was successful because he had integrated, but not confused, skill acquisition with the habitus of wonder and delight in wisdom.

To integrate, but not to confuse: this, I think, is an essential rule to bear in mind if we are committed to the "transcendent value of the liberal arts." If we do, in fact, hold that these arts have transcendent value, then we should let them transcend. We cannot and should not ask an education in the liberal arts to compete, as if on equal footing, with skill-centered or professional educational models in business, nursing, engineering, et cetera. And yet it is difficult to find a college or university in which this is not done. This difficulty stems from a structural dimension in our contemporary universities. Since, for the most part, American universities, Catholic, private, or public, have inherited and adapted the model of the university first organized at the University of Berlin in the nineteenth century, they echo the Enlightenment's encyclopedic approach to knowledge. In this Enlightenment model, knowledge is partitioned into various disciplines of inquiry. In this model, "philosophy" and "theology" become disciplines among disciplines, and indeed all liberal arts are placed on a horizontal plane with sciences, social sciences, and, eventually, applied disciplines like management, nursing, and so on. In this supposed level playing field, no discipline takes precedence over another; knowledge is organized horizontally rather than hierarchically, and any integration requires "cross-disciplinary" or "interdisciplinary" border crossings, which often can amount to little more than a kind of declared truce between specialists. This warms our democratic hearts, but unfortunately, it leaves us high and dry when it comes to any hope of anyone doing the work of integration.

Even further, liberal arts disciplines seem to have made their work that much harder with the very shape of the scholarship they pursue. One of the troubling but fascinating features of the Harvard report is its frank admission that the hard-won critical tradition 
currently dominant in humanities disciplines can suffer from a culture of "relentless critique" that alienates students from the object of their study.

Relentless critique finally disowns any constructive, collective role for the Humanities, standing instead to the side of, and undoing, the collective project. In the classroom, that austere tradition can forbiddingly alienate its own students.

That's the philosophical problem-instead of giving to philosophy and theology the work of integrating, as they traditionally had it, we are left with an invisible, unconscious, ersatz philosophical framework trying to integrate what has been parceled out as distinct and alien areas of knowing. To renew our university's commitment to the transcendent value of the liberal arts, we will need to renew from within our very understanding of the work and the end of the liberal arts themselves. If we don't believe, and argue, that we have in our liberal humanistic tradition something of substance worth preserving and engaging, we can hardly hope to persuade others of the viability or attractiveness of the project.

With this philosophical problem comes a real dollar-and-cents entanglement. In this model of the university, disciplines, organized into departments, and, at a greater scale, into schools or colleges, compete for resources on a level playing field, and so are forced to articulate their goals and objectives over against other schools, colleges, or departments. In most schools I know of, incoming tuition dollars are given to the school or college with which the student is affiliated, in a kind of "winner take all" fashion. Faculty resources are often apportioned in a similar way. Yet, at the same time, professional schools situated within universities depend for anywhere between 30-50\% of their curriculum upon liberal arts and science faculty. In such a system, everyone loses. Colleges of Arts and Sciences will lose because they cannot compete in enrollment with business and engineering in skill acquisition, and then these professional schools in turn will suffer, since, as Arts and Sciences loses its funding, its capacity to support and assist in the education of business and engineering majors diminishes too.

We need to rethink our model of the university, from conceptual arrangements of the "order of knowledge" to the very practical decisions about allotment of tuition dollars. Fiscally, we might work toward a collaborative, revenue-sharing model that apportions tuition dollars based on credit hours rather than place of matriculation. Philosophically, we need to begin to offer cross-college, integrative programs, where as a matter of course, e.g., Arts and Sciences and Business students have the opportunity to work collaboratively, and where Business students are encouraged to have a minor or second major in Arts and Sciences and where Arts and Sciences students have the opportunity for a Business minor or second major. Indeed, as a faculty advisor to some 60 undergraduate majors in our Humanities department, I find myself more and more recommending that students apply to Villanova's Summer Business Institute or something like it so they can gain a skill-set credential along with their education in Humanities.

In my presentations to parents and prospective students, when I have the chance 
to make a pitch for Humanities, I have come to say something like, "You're paying a great sum of money, so of course you are concerned about getting a job, and so of course you'd want to acquire some marketable skills during your time at Villanova. But what else do you want? What else were you hoping college would be?" I note here that Tom's paper points to the fact that some kind of collaboration already exists, since "many professional technical and business education programs...tend at least to include elements of traditional liberal arts education within their core curriculum." What I suggest is that, for Tom's robust vision for the "formation and transformation of students" to take full effect, we must reorient our studies and reorganize our institutions. We must aim together to change and broaden the conversation about what college is for, giving a more complex but more rewarding array of opportunities. In closing, let me suggest that Catholic institutions are uniquely qualified to undertake this task and stand at the vanguard of any such movement, precisely because we can articulate a deep, holistic, and expansive Christian humanism that has the capacity to integrate wisdom and practical skills, and because we are (or ought to be) conscious of our commitment to criteria of success beyond the conventional markers of U.S. News or Kiplingers. But current students have reason to doubt that we have the courage of our convictions, because our institutions are not ordered in their practical working structure by this expansive humanistic vision, and so we must renew our efforts and be willing to break the molds of the conventional university. ${ }^{3}$ As St. Paul says, "be not conformed to the world, but be transformed by the renewal of your minds, that you may prove what is the will of God, what is good and acceptable and perfect."

3 One might argue that there is no reason for a Catholic university to look any different from a secular university down the road. I think we should look different, not because we've received some sort of private revelation, but because the university system we have is broken and needs fixing. The Catholic intellectual tradition offers resources that we can use to repair a broken university, and in this way contribute to the renewal and transformation of higher education in America in a time of crisis and change. 